\title{
Membranózní defekt komorového septa s hemodynamikou defektu Gerbodeho typu při perforaci septálního cípu trikuspidální chlopně
}

\author{
Tomáš Paleček, Jaroslav Lindner*, František Mlejnský*, David Ambrož, Petr Vondráček**, Aleš Linhart \\ 2. interní klinika kardiologie a angiologie, *2. chirurgická klinika kardiovaskulární chirurgie, Všeobecná fakultní nemocnice \\ a 1. lékařská fakulta Univerzity Karlovy, Praha, **Kardiologická ambulance, Rumburk, Česká republika
}

Šedesátiletý muž prodělal v roce 2005 infekční endokarditidu trikuspidální chlopně (etiologicky Staphylococcus aureus). Současně u něj byla diagnostikována bikuspidální aortální chlopeň a membranózní defekt mezikomorového septa. V následujících dvou letech byl bez obtíží; v roce 2008 se však objevila postupně progredující námahová dušnost, pro kterou byl doporučen $\mathrm{k}$ vyšetření v našem kardiocentru. Echokardiograficky byla zjištěna významná aortální regurgitace na degenerativně změněné bikuspidální aortální chlopni do dilatované levé komory, která jevila normální systolickou funkci. Dále byla potvrzena př́tomnost membranózního defektu komorového septa s levo-pravým zkra-

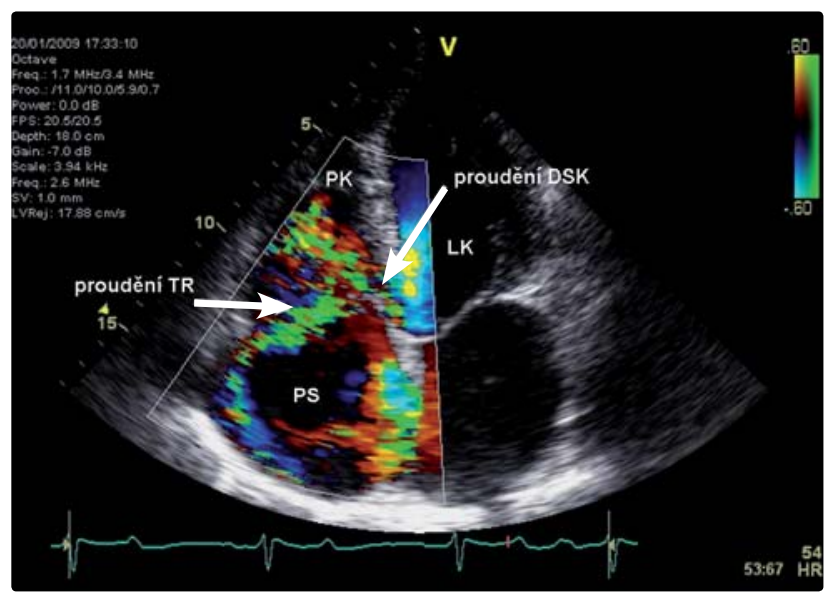

Obrázek 1 Transthorakální echokardiografické vyšetření

V apikální čtyřdutinové projekci je patrno levo-pravé zkratové proudění, pocházející z defektu komorového septa, a excentrické proudění trikuspidální regurgitace (šipky)

DSK - defekt septa komor, TR - trikuspidální regurgitace, PK - pravá komora, PS - pravá síň, LK - levá komora tovým prouděním, s poměrem $\mathrm{Qp}: \mathrm{Qs}=1,4: 1,0$, a maximálním gradientem zkratového proudění $95 \mathrm{~mm} \mathrm{Hg}$, svědčícím, při simultánně měřeném systolickém tlaku na paži $130 \mathrm{~mm} \mathrm{Hg}$, pro hraniční systolický tlak v pravé komoře, resp. plicnici, rovnající se $35 \mathrm{~mm} \mathrm{Hg}$ (obrázky 1 a 2). Také byla popsána dilatace pravé komory i pravé síně a významná, excentricky jdoucí trikuspidální regurgitace, jejíž maximální gradient činil $120 \mathrm{~mm} \mathrm{Hg}$, což by naopak, při odhadu zvýšeného tlaku v pravé síni na hodnoty 15-20 mm Hg, ukazovalo na těžkou hypertenzi v plicnici s odhadem systolického tlaku 135-140 mm Hg (obrázky 3 a 4). Katetrizační vyšetření potvrdilo významnou aortální regurgitaci

Adresa: MUDr. Tomáš Paleček, 2. interní klinika kardiologie a angiologie, VFN a 1. LF UK, U nemocnice 2, 12808 Praha 2, Česká republika, e-mail: Tomas.Palecek@lf1.cuni.cz 


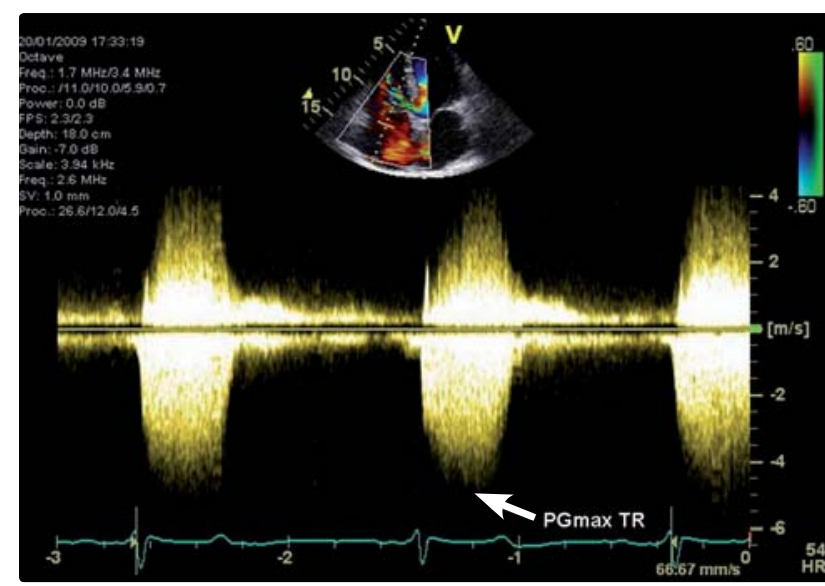

Obrázek 3 Transthorakální echokardiografické vyšetření

Kontinuálně dopplerovský záznam trysky trikuspidální regurgitace s maximálním gradientem 120 mm Hg (šipka)

TR - trikuspidální regurgitace

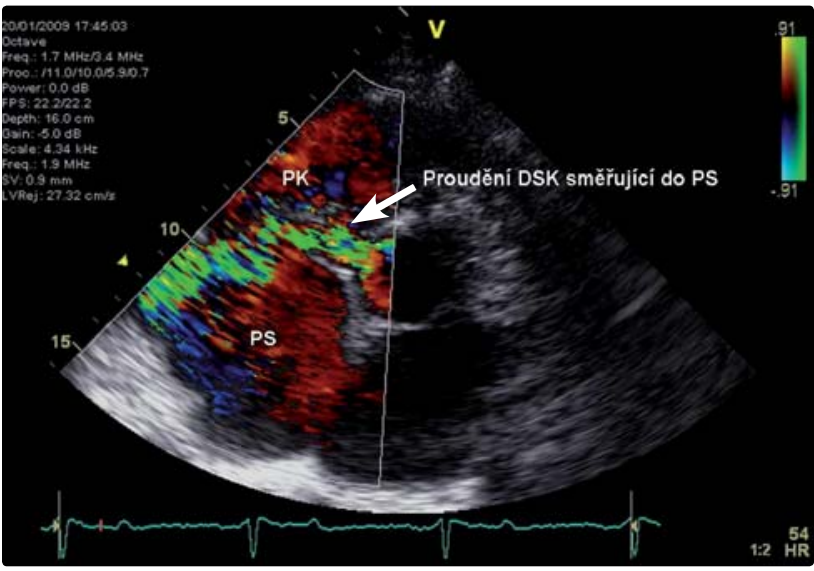

Obrázek 4 Transthorakální echokardiografické vyšetření

V modifikované apikální projekci je patrno zkratové proudění defektu septa komor, procházející preses perforaci v septálním cípu trikuspidáln chlopně do dutiny pravé síně (šipka)

DSK - defekt septa komor, PK - pravá komora, PS - pravá sín̆

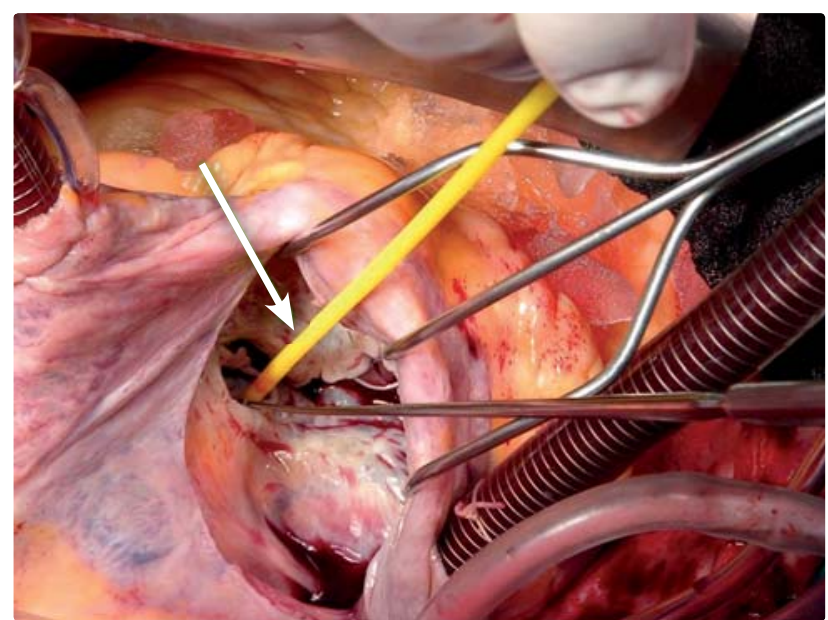

Obrázek 5 Peroperační zobrazení defektu v septálním cípu trikuspidáln chlopně a defektu komorového septa

Šipka ukazuje na tyčinku procházející oběma patologiemi

a neprokázalo př́tomnost plicní hypertenze; střední tlak v plicnici činil $23 \mathrm{~mm} \mathrm{Hg}$, systolický tlak $31 \mathrm{~mm} \mathrm{Hg}$.

Příčinou diskrepance mezi neinvazivně odhadovaným tlakem v plicnici podle gradientů zkratového proudění a trikuspidální regurgitace byla skutečnost, že levo-pravé zkratové proudění $\mathrm{z}$ defektu septa komor bylo přes perforaci v septálním cípu trikuspidální chlopně směřováno též do pravé síně, což bylo popsáno při zpětném hodnocení předchozího echokardiografického vyšetření (obrázek 4). Gradient tohoto proudění, braný jako gradient „klasické“ trikuspidální regurgitace, ukazoval na falešně vysoké hodnoty tenze v plicnici. Hemodynamicky tedy situace imitovala fyziologii tzv. Gerbodeho defektu, což je vrozený či získaný levo-pravý zkrat mezi levou komorou a pravou síní.

Nemocný byl indikován ke kardiochirurgickému výkonu, při kterém byla bioprotézou nahrazena aortální chlopeň a perikardiální záplatou uzavřen membranózní defekt septa komor. Po otevření pravé síně byla potvrzena perforace septálního cípu trikuspidální chlopně o šírce $1,5 \mathrm{~cm}$ (obrázek 5), pravděpodobně související s dříve prodělanou infekční endokarditidou. Defekt cípu byl ošetřen perikardiální záplatou a následně byla provedena plastika trikuspidální chlopně podle De Vegy. 